Jurnal Hunafa: Studia Islamika, Volume 17, Number 2, p. 1-190

E-ISSN: $2355-7710$

P-ISSN: 1411-125X

\title{
THE USE OF MUSEUM FOR CULTURAL DAKWAH PURPOSES
}

Samsinas ${ }^{1}$

${ }^{1}$ FUAD, IAIN Palu, Palu, samsinas29@yahoo.co.id

\begin{abstract}
This paper discusses the museum as a means of cultural da'wah. There are two main problems namely; how to interest visitors to the museum as a cultural propaganda suggestion and how is the intention of the museum visitors as a means of cultural propaganda? This study uses quantitative research types with analysis of cultural anthropological research and the science of da'wah. To measure the progress of this cultural propaganda can be seen through the level of visitor interest in Islamic artifacts and the level of visitor visits. The method and sample conducted a survey of 25 visitors using a questionnaire. The results found that the level of interest in Islamic artifacts and culture is influenced by the intention of visitors to visit the museum as a cultural da'wah instrument. Intense of communication according to the communication or da'wa patterns prevailing in the museum where a person or group of people came, observed, studied, and understood everything related to Islam and culture that has been influenced by Islam through artifacts in the Central Sulawesi Museum over and over again.
\end{abstract}

Keyword: Museum, Cultural Preaching, Interest, and Intention

Abstrak. Makalah ini membahas museum sebagai sarana dakwah budaya. Ada dua masalah utama yaitu; Bagaimana menarik pengunjung museum sebagai sugesti dakwah budaya dan bagaimana niat pengunjung museum sebagai sarana dakwah budaya? Penelitian ini menggunakan jenis penelitian kuantitatif dengan analisis penelitian antropologi budaya dan ilmu dakwah. Untuk mengukur kemajuan dakwah budaya ini dapat dilihat melalui tingkat minat pengunjung terhadap artefak islami dan tingkat kunjungan pengunjung. Metode dan sampel melakukan survei terhadap 25 pengunjung dengan menggunakan kuesioner. Hasil penelitian menemukan bahwa tingkat minat terhadap artefak dan budaya Islam yang dipengaruhi oleh Islam dengan niat mengunjungi pengunjung museum menunjukkan adanya minat dan niat dakwah budaya karena adanya komunikasi yang intens sesuai dengan pola 
komunikasi atau pola dakwah. berlaku di museum tempat seseorang atau sekelompok orang datang, mengamati, mempelajari dan memahami segala sesuatu yang berhubungan dengan Islam dan budaya yang telah dipengaruhi oleh Islam melalui artefak di Museum Sulawesi Tengah berulang kali.

Kata Kunci: Museum, Budaya Dakwah, Daya Tarik, dan Minat

\section{Introduction}

Nowadays, Indonesian Muslims have an idea to build a museum related to the Prophet and or Islamic da'wah, which is named the Rasulullah Museum. The idea of building the Rasulullah Museum is raised by the Indonesian Mosque Council (DMI), chaired by Yusuf Kalla. In implementing this idea, DMI collaborated with the Islamic World League (LDI), which was also supported by the Indonesian government. The Rasulullah Museum, which is in the Ancol Jakarta area and is currently in the process of being developed ${ }^{1}$, is a manifestation of the enthusiasm of Indonesian Muslims for the advancement of civilization and the spread of Islam, making the museum a means of preaching.

Before this museum was founded, many other museums were established in various places and various regions throughout Indonesia. However, the existing museums do not fully function as Islamic museums. Generally, it can be referred to as a cultural museum and a national history museum, which is related to the da'wah of Islam, the history of the nation's struggle, or the culture of society so that the existing museums are more identical with the Cultural Museum. One of them is the Central Sulawesi Cultural Museum, which is in Palu City.

Museums are not only a means of education but also a center for information on various things that happen to human society in the past and today. Visiting the museum seems to get a lot of information about regional natural

\footnotetext{
${ }^{1}$ Muhyiddin, “Ancol Resmi Jadi Lokasi Museum Rasulullah SAW Terbesar Dunia”, 2020
} 
products, historical stories of the nation, or the various works of the people, both written, pictured, or formed in various artifacts.

The city of Palu has a Muslim majority community, indicating that information on Islamic da'wah has occurred in the Palu area written or stored in the Central Sulawesi Cultural Museum. If there is such a thing, the Cultural Museum can also be called a means of da'wah for its visitors or rather a means of cultural da'wah.

\section{Literature Review}

Previous Museum Studies

a) Joseph-Mathews, Bonn, and Snepenger (2009):

Conceptually, Joseph and his friends focus on the problem of behavioral intention, service environment (atmosphere, design and layout, social factors), symbolic perceptions of the museum. The method and sample are conducting a survey of 500 visitor respondents at four locations of hedonic service attractions in Florida (USA), such as museums, aquariums, performing arts centers, and zoos. The findings are; Environmental factors play an important role in determining the intention to behave in hedonic services. Consumer symbolic perception (meaning) influences behavior intention. Consumers evaluate the service environment (atmosphere, design and layout, social factors) differently depending on the meaning of a service environment. The service environment can be used as a differentiation tool to perpetuate the meaning and uniqueness of the brand in consumers' minds, thereby creating a competitive advantage for hedonic facilities and encouraging repeat purchases. ${ }^{2}$

${ }^{2}$ S. Joseph-Mathews, M.A Bonn, and D. Snepenger, “Atmospherics and Consumers' Symbolic Interpretations of Hedonic Services", International Journal of Culture, Tourism, and Hospitality Research, Vol. 3 No. 3, (2009): 193-210. 
b) Radder and Han (2013)

Radder and Han's keyword study is on the problem of perceived quality, satisfaction, conative loyalty. Methods and Samples conducted a survey of 26 visitors at three heritage museums in South Africa. The finding is that perceived quality consists of two service-based dimensions (service interaction and proof of service) and two product-based dimensions (product functionality and product enrichment). Visitor quality perceptions have an indirect effect (through satisfaction) and a direct effect on behavioral intentions or conative loyalty. ${ }^{3}$

b) Muscat, Zehrer, and Johns (2013)

The main concept of his study is the visitor experience and the quality of the visitor experience. Methods and Samples conducted qualitative exploratory research conducted with data from 29 postgraduate students at the University of Canberra, Australia. The mobile ethnography method is used to collect data and study visitors' experiences from generation Y (Millennials) to the services of the Australian National Museum in Canberra. The key finding is that knowledge of customer experience is essential in the museum industry. Museum management needs to be involved in measuring visitors' experience of museums, particularly with improving service delivery processes. Museum administrators should properly manage museum service experiences by collecting, evaluating, storing, and reusing visitor experience data. The parking lot needs to get the attention of Generation $Y$ because it gives the initial impression of a visitor when entering the museum. In general, museum employees are very positive in serving. Souvenir shops and restaurants received positive reviews from visitors. ${ }^{4}$

Museum

${ }^{3}$ L. Radder, and X. Han, "Perceived Quality, Visitor Satisfaction and Conative Loyalty in South African Heritage Museums", International Business \& Economics Research Journal, Vol. 12 No. 10, (2013): 1261-1272.

${ }^{4}$ M. Muskat, B. Muskat, A. Zehrer, and R. Johns, "Generation Y: Evaluating Services Experiences through Mobile Ethnography”, Tourism Review, Vol. 68 No. 3, (2013): 55-71. 
The museum comes from the Latin word "mouseion", which means a place to store ancient objects. In Greek, it is called "Muze" which means a group of nine goddesses $^{5}$. This definition is motivated by the history of the museum, which was originally a shrine to the goddess Muze in the classical Greek era, then developed into a repository for collections of public art and educational objects, including (works) of researchers, students, and students. Webster's New Collegiate Dictionary defines a museum as an institution that devotes itself to the acquisition, maintenance, research, and exhibition of objects that have or are a lasting attraction. Furthermore, the museum is a permanent non-profit institution that functions to provide services and development openly to the community, acquiring, maintaining, connecting, and exhibiting objects as evidence from humans and their environment for educational, research, and entertainment purposes. ${ }^{6}$

Based on the International Council of Museums (ICOM), the definition of a museum has evolved in line with society's developments:

"The museum is a non-profit and permanent institution in community service and its development is open to the public, which acquires, preserves, researches, communicates and exhibits human heritage/heritage, both tangible and intangible, and the environment for educational, study, and educational purposes. And fun".

From various references, several definitions of museums can be obtained: (a). A museum is an institution, a place for storing, maintaining, securing, and utilizing material evidence of human culture and nature and its environment to

\footnotetext{
${ }^{5}$ K. Brown, and F. Mairesse, "The Definition of the Museum through Its Social Role." Curator: The Museum Journal, 61(4), (2018): 525-539. https://doi.org/10.1111/cura.12276

${ }^{6}$ Roby Ardiwidjaja, 2018

${ }^{7}$ ICOM ICOM Code of Ethics for Museums. Paris: International Council of Museums. 2013. Also see, T. Komarac, "A New World for Museum Marketing? Facing the Old Dilemmas while Challenging New Market Opportunities”, Trziste, Vol. 26 No. 2, (2014): 199-214.
} 
support efforts to protect and preserve the nation's cultural wealth ${ }^{8}$. (b). According to ICOM, a museum is an institution that is permanent, non-profit, serving the public, open to the public, which collects, cares for, researches, communicates, and exhibits material evidence of humans and their environment for study, education, and tourism. (c). The museum is a vehicle that has a strategic role in strengthening the community's identity, including the surrounding community. (d). Museum as part of social institutions, also as a vehicle to provide an overview and educate about the development of nature and human culture to the community and the public. ${ }^{9}$

The purpose of the museum, among others; (1) For the preservation of cultural heritage in a broad sense, it means not only preserving physical, cultural heritage objects but also preserving the meaning contained in those objects in a system of values and norms. (2) Introducing the roots of national culture is used in composing national culture development, especially in national education. (3) Providing various kinds of sources of inspiration for innovative creativity needed in national development through recreational nuances for visitors. (4) Anticipating the impact of globalization, which gives changes in various aspects of sociocultural, economic, and political life through the preservation and protection of the noble values of Indonesian culture at the local, regional and national levels. ${ }^{10}$

While the function of the Museum According to ICOM, as; Collection and security of natural and cultural heritage, storage of scientific documentation and research, conservation and preservation, distribution of knowledge to the public, introduction, and appreciation of arts, introduction to culture between regions and nations, visualization of nature and culture, mirrors of growth of human

\footnotetext{
${ }^{8}$ J. K. Nielsen, “The Relevant Museum: Defining Relevance Ilin Museological Practices." Museum Management and Curatorship, 30(5), (2015): 364-378. https://doi.org/10.1080/09647775.2015.1043330

${ }^{9}$ Ibid.

${ }^{10} \mathrm{Ibid}$
} 
civilization, generators of taste pious and give thanks to God Almighty. ${ }^{11}$ The Museum plays an important role in providing an understanding of the identity of a nation, reflecting preservation of the nation's culture and also preserving and conveying the link between the collective memory of the past and the present for the benefit of the future to the community. ${ }^{12}$ Peter Van Mensch said that the three basic functions of the Museum, namely, research (research), maintenance (preservation), and communication (communication). ${ }^{13}$

\section{Cultural Da'wah}

Etymologically, the word da'wah comes from the verb $d a^{\prime} a-y a d^{\prime} u$ - $d a^{\prime} w a t a n$, which means to invite, call, and also invite. ${ }^{14}$ In the Qur'an, the word da'wah has several meanings, such as Istighotsah-asking for help (QS. Al-Baqarah: 23), worship (QS. Yunus: 106), Prayer (Surah Al-Kahf: 28), Nidaa' and tasmiyah (Surah An-Nuur: 63), Prayer. (QS. Ghafiir: 60). If the root word is added with the word يلإ as contained in the Qur'an Surah Yunus: 25, "Allah calls (humans) to Darussalam (heaven) and shows those who wants the straight path (Islam)," ${ }^{15}$ The meaning of terminology da'wah is an encouragement, invitation or calling to mankind to follow, explore and realize Islamic teachings because Islam is a straight path.

The definition of da'wah, according to the experts quoted by Moh. Ali Aziz ${ }^{16}$ as follows.

According to Abu Zakaria, da'wah is;

\footnotetext{
${ }^{11}$ Ibid

${ }^{12}$ Roby Ardiwidjaja, 2020

${ }^{13}$ Peter Van Mensch, "The Musealisation Of Knut. Dilemmas in the Relationship between Zoom and Museum", Comcol Newsletter, No. 13, (2011): 4-7

${ }^{14}$ A. W. Munawwir, Kamus al-Munawwir, Edisi ke-2, (Surabaya: Pustaka Progresif, 1997) p. $406-407$

${ }^{15}$ Kementerian Agama RI, Alqur'an dan Terjemahnya, (Bandung, Fokus Media, 2010)

${ }^{16}$ Moh Ali Aziz, Ilmu Dakwah, (Jakarta: Kencana, 2004), p. 11
} 
"The efforts of scholars and people who have knowledge of Islam to teach the general public in accordance with their abilities about the things they need in the world and religious affairs." ${ }^{17}$

Ali bin Salih al-Murshid, preaching is "A system that serves to explain truth, virtue, and guidance while at the same time exposing various falsehoods and their media and methods through a number of other techniques, methods, and media." ${ }^{18}$

Furthermore, according to M. Arifin, da'wah is.

"An invitation activity in the form of oral, written, behavioral and so on which is carried out consciously and planned to influence other people individually or in groups so that there will be an understanding, awareness, attitude, appreciation, and practice of religious teachings; where the message is delivered, there is no element of coercion. "19

B.J Boland defines da'wah as; "Islamic Propaganda, not only through dissemination and publication but also actions and activities in all social life spheres. In other words, da'wah is a comprehensive effort to Islamize society. Meanwhile, Johan Meuleman said that "da' wah is basically an activity that leads to strengthening and deepening the faith of Muslims, and developing their way of life in accordance with Islamic principles." ${ }^{20}$

Based on some of the definitions above, da'wah is a conscious effort in inviting, conveying, guiding, and empowering Muslims to carry out Islamic teachings with the awareness and that the purpose of all practice or worship is to seek the pleasure of Allah SWT and the essence of da'wah is a change from bad conditions to conditions that are not good. Well, from a good condition to a better condition, either by or against individuals and communities.

Da'wah has several components, which are da'wah implementers (da'wah subjects), da'wah recipients (da'wah objects), message content (da'wah material),
${ }^{17} \mathrm{Ibid}$
${ }^{18} \mathrm{Ibid}$
${ }^{19} \mathrm{Ibid}$
${ }^{20} \mathrm{Ibid}$. 
methods of delivering messages (da'wah methods), tools used to convey da'wah messages (da'wah media), and organizations that provide ongoing dakwah activities (da'wah institutions/facilities) ${ }^{21}$. However, Masdar limits the elements of da'wah, namely da'i (da'wah actors), mad'u (da'wah partners), maddah (da'wah material), wasilah (da'wah media), thariqah (method), and atsar (da'wah effect). ${ }^{22}$ However, the existence of preaching facilities is an important element so that the da'wah activities are accommodated institutionally.

Culture comes from the English word "culture," which means culture. In cultural communication, each person has their symbols, meanings, choices, and patterns that reflect the many cultures in which it was a part of life. ${ }^{23}$ Cultural da'wah means the pattern of da'wah communication that follows the cultural communication patterns prevailing in museums ${ }^{24}$.

The forms of preaching can be seen in several ways, among others; delivery/socialization (tabligh), guidance/deepening/development of insight/counseling (irsyad), institutional and resource management (tadbir), strengthening/empowerment/independence (tamkin ${ }^{25}$. In this regard, da'wah can be called Islamic communication or more precisely, Islamic communication is the development of a form of da'wah activity.

Conceptual Framework

\footnotetext{
${ }^{21}$ N. Nurdin, “To Dakwah Online or not to Dakwah Online. Da'i Dilemma in Internet Age.”, Al-Mishbah : Jurnal Ilmu Komunikasi dan Dakwah, 10(1), (2014): 21-33.

${ }_{22}$ Masdar Helmi, Dakwah dalam Alam Pembangunan, (Semarang: CV Toha Putra), p. 31

${ }^{23}$ Brend D Ruben, Komunikasi dan Perilaku Manusia. (Jakarta, Rajawali Press, 2013), p. 377.

${ }^{24}$ N. Nurdin, \& H. Maddini, "Sejarah Dakwah Dato Karama: Menelusuri Ulama Sumatera Barat Penyebar Islam Di Lembah Palu”, Al-Mishbah: Jurnal Ilmu Dakwah dan Komunikasi, 14(2), (2018): 205-239.

${ }^{25}$ N. Nurdin, \& Rusli, “Spiritualising New Media: The Use of Social Media for Da'wah Purposes within Indonesian Muslim Scholars." Jurnal Komunikasi islam, 3(1), (2013): 1-21. http://jki.uinsby.ac.id/index.php/jki/article/view/55
} 
In one sense, the museum is a center of information or a vehicle to educate the community and the public about the development of nature and human culture. A person or group of people (inviting each other) to visit the museum, observe, study, and explore various Islamic and cultural artifacts that are influenced by Islam in the museum can be called actors and/or objects of cultural da'wah.

It is called cultural da'wah because it follows a cultural communication pattern that every visitor follows the prevailing communication pattern in the museum, namely visiting (active visitors), observing, studying, understanding, and mastering various Islamic artifacts and cultures that are influenced by Islam. Activities of visitors to receive the message of Islam (as an object of da'wah) and convey it (as the subject of preaching). The message of Islam itself is categorized as da'wah material, and museums as a vehicle or means and artifacts are media.

Extracting Islamic messages can be measured through the level of interest in Islamic artifacts or cultural artifacts that have Islamic influence and the status of the intention of visiting museum visitors. Someone will choose Islamic artifacts and explore them if there is an element of interest in Islam. Serious interest will generate the intensity of the visit. The level of interest will be followed by the level of visits, which will increase insight into Islam. The conceptual framework of this study is depicted in figure 1 below: 


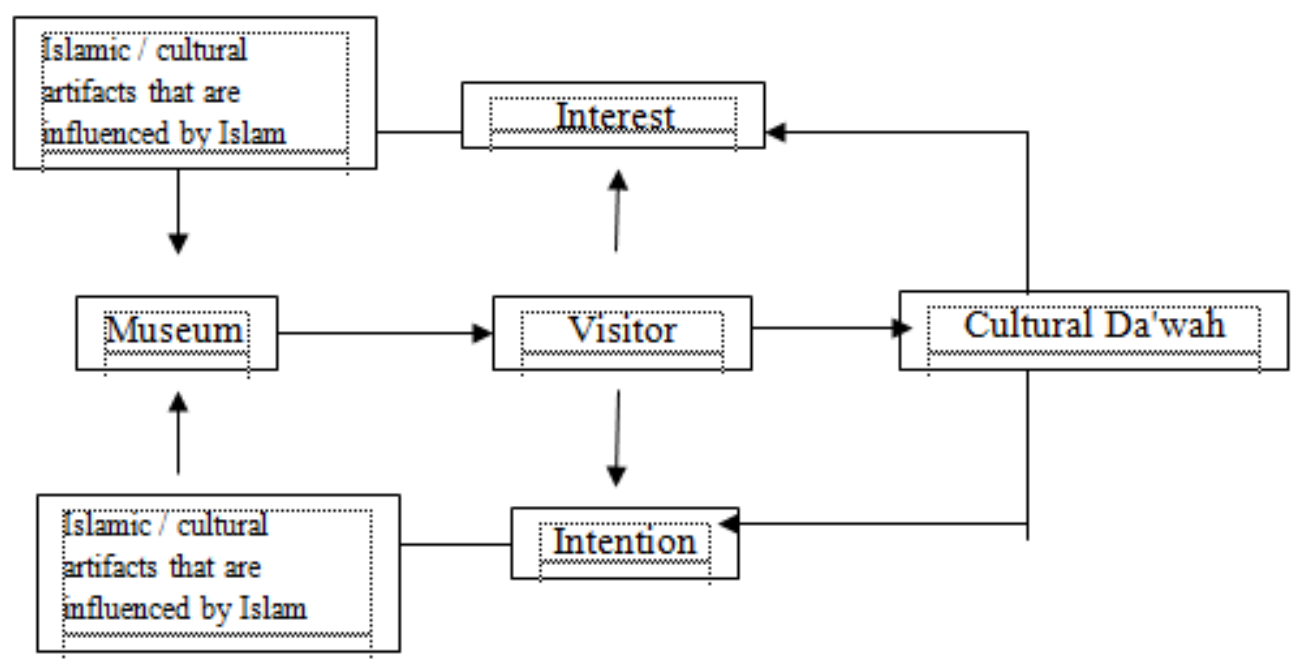

Figure 1. Conceptual Framework

\section{Methodology and Approach.}

The fundamental question in this research is, how can a museum be called a means of cultural da'wah? Answering this question will make everyone understand cultural da'wah. This research uses quantitative research. Approach to analysis using the approach of cultural anthropology and da'wah science. The cultural anthropology approach aims to see the cultural substance of society through the artifacts in the museum. Meanwhile, the da'wah approach sees Islamic messages in museum artifacts, and visitors themselves can be called actors as well as objects of da'wah. Islamic messages in artifacts can be called da'wah material, artifacts as media and museums can be called da'wah tools.

In collecting data using several techniques, observation of documentation, namely examining the museum documents of photos, manuscripts, books, scripts, letters, and others, can be information or research data. Then the next technique is a questionnaire by surveying 25 visitors (adults) to measure the level of visitors' interest in Islamic artifacts, and the intention of visiting museum visitors that to measure the existence of da'wah activity is through the level of interest and level of intention. 


\section{Research Result}

Central Sulawesi Provincial Museum and Artifacts Collection

Central Sulawesi Museum is one of the provincial museums in Indonesia and is in Palu City, Jalan Kemiri No. 23 Kelurahan Kamonji, West Palu Subdistrict, Palu City. The history of the establishment of this Museum begins with the results of an exploration of a cultural observer from Central Sulawesi, Masyhuddin Masyuda BA. The idea is to establish a museum outlined in an article entitled "The Perspective on the Development of the State Museum of Central Sulawesi Province" presented at the museum science upgrading at the National Museum in $1975 .^{26}$

The construction of the Museum building began in 1977 on a land area of $18,330 \mathrm{~m}^{2}$ and was completed in 1978. The number of collections at that time was around 133, consisting of 10 pieces of Ethnographic and History and 20 Keramologics. ${ }^{27}$ In the same year, the first Museum leader in the history of the Central Sulawesi museum was appointed, namely the initiator of the establishment of the Museum named Mashudin Mashuda, BA. (1978-1987 AD).

The Museum's establishment is a mandate in the 4th paragraph of the 1945 Constitution, namely "Educating the Life of the Nation." And article 32, paragraph 1 of the 1945 Constitution states: "The state advances Indonesia's national culture in the midst of world civilization by guaranteeing society's freedom to maintain and develop its cultural values."

The vision of the Central Sulawesi Cultural Museum is the realization of the Museum as a source of knowledge and regional cultural tourism objects for the advancement of society and the preservation of the nation's culture. While the mission is to instill noble cultural values about people's lives through museum collections, making museums a source of non-formal education and recreational

\footnotetext{
${ }^{26} \mathrm{https} / / /$ situsbudaya.id/museum-negeri-provinsi-sulawesi-tengah/ accessed 30 October 2018

${ }^{27} \mathrm{Ibid}$.
} 
facilities, fostering awareness in the field of science and technology, and increasing appreciation and creativity to various stakeholders.

The collection of the State Museum of Central Sulawesi Province until 2017 amounted to 7,565. The number of artifacts is classified into ten categories as explained in the following table.

Table I;

Central Sulawesi Cultural Museum Artifact Collection Data

\begin{tabular}{|c|l|c|c|}
\hline No & Collection type & Code & Total \\
\hline 01 & Geology & $(01)$ & 59 \\
\hline 02 & Biology & $(02)$ & 29 \\
\hline 03 & Ethnographics & $(03)$ & 5.332 \\
\hline 04 & Archeology & $(04)$ & 623 \\
\hline 05 & History & $(05)$ & 212 \\
\hline 06 & Numismatics / Heraldika & $(06)$ & 435 \\
\hline 07 & Philology & $(07)$ & 27 \\
\hline 08 & Kramologics & $(08)$ & 831 \\
\hline 09 & Art & $(09)$ & 16 \\
\hline 10 & Technology & $(10)$ & 5 \\
\hline & & & 7.565 \\
\hline
\end{tabular}

Data source: Central Sulawesi Museum Collection Data Document 2018 
These artifacts are stored at the museum in various forms. Some are pure (original) artifacts, and some are in the form of pictures, photos and some are in the form of miniatures (mockups) of buildings/objects and the form of duplicates. Original artifacts such as the Al-Qur'an, keris, traditional clothes, tools (farming, kitchen, war, and hunting), and others. Whereas in the form of photos are graves that are impossible to keep in museums such as the tombs of Guru Tua, Datokarama, Pue Njidi, and others. Whereas in the form of miniatures are mosques and historical buildings that are also impossible to keep in museums because the artifacts are attached to the earth so that they must be stored in the form of photographs to make miniatures. The museum has created or compiled artifacts in catalog form.

\section{Islamic Artifacts}

Islamic History Books and Manuscripts.

Museum artifacts related to Islam are presented in the historical narrative of the ulama or figures who preached Islam in Palu or related to it, such as; history Datokarama or Abdullah Raqi was a da'i figure or carrier of Islam for the first time in Palu. Abdullah arrived in Palu from around 1606 AD to 1650 AD (17th century AD) and died in 1709 AD (early 18th century AD). He comes from Ten Koto, Minangkabau, West Sumatra. He is known to the public because of his sacredness so that the Kaili people (the name for the original tribe of the Palu people) call him Datukarama. Also, there is a character named Pue Njidi - the first Islamic recipient in the Palu valley who was also a king who supported the preaching of Islam in the early days. He is a student of Datokarama.

Furthermore, the history of Idrus bin Salim al-Jufri) who was named AlHabib al 'Alaamah or the Old Teacher of the Al-Khairaat Islamic Boarding School in Palu, was born in Hadramaut on March 15, 1892 AD (15 Sya'ban 1309 H) and 
died on December 22, 1969 AD (12 Sawwal 1389 H). Also, some books spread the religion of Islam in Palu, which comes from Bugis, Makassar, and Java, as well as books and texts related to cultures that have had other Islamic influences.

Al-Qur'an

The Al-Qur'an in question is the Qur'an, which is hundreds of years old. There are three types of the Old Al-Qur'an in the Central Sulawesi Museum, they are; (a) The Al-Qur'an that is made of bark, hundreds of sheets of the Al-Qur'an are made of banyan bark, and the cover is made of animal skin. According to research from the Ministry of Religion of the Republic of Indonesia, this Al-Qur'an is thought to have been made in the 17th century in the era of Datokarama or Abdullah Raqi, a carrier of Islam as well as a preacher. from Minangkabau to Central Sulawesi. (b) The Al-Qur'an was written in the 19th century during the da'i from South Sulawesi or Bugis and Makassar. The Al-Qur'an writing uses imported paper from Europe, about $40 \mathrm{~cm}$ long and $10 \mathrm{~cm}$ thick. The edges of the paper are engraved with the form of flora or flowers with a combination of 3 colors (red, yellow, and green) and use Chinese ink to make this Al-Qur'an look very beautiful. At each Juz transition in the Koran, a full page is found engraved with the typical flora of Central Sulawesi, describing that this Koran was made in Central Sulawesi. (c) The Al-Qur'an was written in the late 19th century or early 20th century AD.

Keris

Keris is one of the archaeological artifacts that contain Islamic historical value because at the core of the keris is inscribed with Malay Arabic calligraphy, which is carved in such a way that it can be read that says, "if you want to do 
something, you have to think about it first". This means that this article contains wise advice to think carefully before acting, including using the keris.

Tomb

The tomb is one of the important artifacts in historical spatial analysis. This is due to human activity in sacred tombs and then influencing civilization. The tomb has artifacts in the form of tombstones, which can be evidence of preaching activity in the past: if we look at the shape, type of stone, decoration, and style of the letters the tombstone has. In the Museum, these tombs are displayed in the form of framed photos such as; Datokarama Tomb, Tomb of old Teacher, Tomb of Imam Masjid Jami 'Hi. Abdul Rasyid Dg Tatantu, Tomb of Pue Njidi, and others.

Jami Mosque '

A mosque is also a type of building that is one of the archaeological objects. At the time of the development of Islam, the mosque was one of the monumental proofs that Islam was accepted by the local community. The construction of a mosque at a job marks that Islam is officially accepted as the religion of the kingdom. At the Museum, the Jami Mosque 'is displayed in the form of a photo. However, its form still exists and is located on Jalan Wahid Hasyim, Ujuna Village, Palu City.

The Jami' Mosque building is estimated to have stood around 1905-1908 AD. The Kaili-Bugis culture characterizes it. It was founded by three families who are still relatives, one of which is mentioned in several references is Pua Langgai with the real name Haji Ibrahim or Hi. Borahima. This building can still be used today, both as a place of worship as well as a place for community recitation 
activities. However, over time, this mosque underwent renovations so that the original part of the mosque was only the pulpit of the mosque.

\section{Traditional Dress}

The bride's traditional dress is called Nggembe in the form of a rectangle with a round neck and waist length. The sarong or cloth for the lower part is called Buya Sabe Kumbaja, decorated with gold or silver-colored lights. Women's clothes are equipped with gold or silver accessories on the head, and earrings called Dali taroe, long bracelets called Ponto ndate, and necklaces called gemo. The clothes for men are called Koje/Puruka Pajana or Ceki clothes, in the form of long sleeves with knee-length tights with a head covering called Siga and a keris pinned to the waist. But most of the grooms wear long sarongs or trousers. This Kaili wedding dress can be said to be influenced by Islam because it appears to cover the genitals of both men and women.

\section{Museum as A Means of Cultural Da'wah}

The study results found that Islamic artifacts and artifacts that talk about

the culture of the people of Palu City who were influenced by Islam were collected in the form of photos of various sizes, displays, mockups, and written documents. These artifacts in the context of da'wah can be referred to as da'wah media.

The artifacts are not only beautiful collections that contain artistic value but also have a lot of history/stories. Each story has wisdom values or moral messages for the community/visitors, the teachings of the scholars, the philosophy of life and advice of the ancestors, as well as about patterns and developments in people's lives from time to time that can make people aware of God's power and to be always grateful. The Museum also talks about the cultural relations between the 
people and the preaching of Islam in the land of Kaili in the past brought by da'i or ulama who have a myriad of relics both stored in the Museum and outside the Museum. The Museum can help the public/visitors understand well about Islam and the influence of Islamic teachings in the cultural epicenter of the Palu people, all of which can be called da'wah material.

The activity of studying and inviting to understand Islamic messages in the Museum can be referred to as cultural da'wah, where the communication pattern is by the system or communication pattern prevailing in the Museum, namely, the manager only displays the entire collection of existing artifacts and serves visitors. However, the manager here can be called a passive da'wah subject. It is the visitor who becomes the active da'wah subject as well as the object of preaching. It is called an active da'wah subject because visitors consciously and initiative come to visit the Museum according to their interests by selecting materials or artifacts of interest and according to their time and opportunity and even come repeatedly.

\section{Visitor Conditions}

To enter the artifact spaces, the Museum applies a payment system or admission fee, for students and students of Rp. 3000, - while for the public Rp. $10,000,-$. As an illustration, the following shows the general conditions of visitors to the Central Sulawesi Museum in 2013-2017 as follows. 
Table II. Condition of Central Sulawesi Museum Visitors 2013-2017

\begin{tabular}{|c|c|c|c|c|c|c|c|c|c|c|c|c|c|}
\hline \multirow{2}{*}{ Year } & \multicolumn{12}{|c|}{ Month } & \multirow{2}{*}{ Total } \\
\hline & $\begin{array}{l}\mathrm{Ja} \\
\mathrm{n}\end{array}$ & Feb & $\begin{array}{l}\mathrm{Ma} \\
\mathrm{r}\end{array}$ & $\begin{array}{l}\text { Ap } \\
r\end{array}$ & $\begin{array}{l}\mathrm{Ma} \\
\mathrm{y}\end{array}$ & Jun & Jul & $\begin{array}{l}\mathrm{Au} \\
\mathrm{g}\end{array}$ & Sep & Okt & $\begin{array}{l}\text { No } \\
\mathrm{v}\end{array}$ & $\begin{array}{l}\text { De } \\
\mathrm{s}\end{array}$ & \\
\hline 1 & 2 & 3 & 4 & 5 & 6 & 7 & 8 & 9 & 10 & 11 & 12 & 13 & 14 \\
\hline 2013 & $\begin{array}{l}45 \\
3\end{array}$ & 350 & 542 & 520 & $\begin{array}{l}743 \\
5\end{array}$ & $\begin{array}{l}164 \\
7\end{array}$ & $\begin{array}{l}13 \\
8\end{array}$ & 225 & 928 & $\begin{array}{l}111 \\
6\end{array}$ & 898 & $\begin{array}{l}70 \\
9\end{array}$ & 14961 \\
\hline 2014 & 87 & 833 & 289 & 201 & 834 & $\begin{array}{l}474 \\
1\end{array}$ & 24 & 44 & 310 & 157 & $\begin{array}{l}113 \\
5\end{array}$ & $\begin{array}{l}21 \\
1\end{array}$ & 8866 \\
\hline 2015 & $\begin{array}{l}61 \\
5\end{array}$ & 298 & 645 & 358 & $\begin{array}{l}133 \\
3\end{array}$ & 842 & $\begin{array}{l}16 \\
7\end{array}$ & $\begin{array}{l}983 \\
3\end{array}$ & 427 & 952 & 300 & $\begin{array}{l}49 \\
1\end{array}$ & 16261 \\
\hline 2016 & $\begin{array}{l}32 \\
4\end{array}$ & $\begin{array}{l}127 \\
1\end{array}$ & 882 & 307 & $\begin{array}{l}121 \\
4\end{array}$ & 618 & $\begin{array}{l}10 \\
7\end{array}$ & 206 & $\begin{array}{l}1347 \\
3\end{array}$ & 642 & 669 & $\begin{array}{l}66 \\
5\end{array}$ & 20378 \\
\hline 2017 & $\begin{array}{l}71 \\
4\end{array}$ & $\begin{array}{l}111 \\
0\end{array}$ & 812 & 529 & 527 & 97 & $\begin{array}{l}15 \\
8\end{array}$ & 538 & 587 & 830 & $\begin{array}{l}140 \\
1\end{array}$ & $\begin{array}{l}94 \\
6\end{array}$ & 8249 \\
\hline Total & & & & & & & & & & & & & 68.661 \\
\hline
\end{tabular}

Data source: Central Sulawesi Museum Visitor Data Document 2018

The table above shows that the number of visitors has increased significantly each year. Most visitors occurred in 2016, and the least visitors were in 2017. Visitors tend to be slightly on average in January and July, and in the first month of entering the semester and after long holidays for students and students. Most visitors occurred in August 2015, which is 9833 visitors. 
Table III

Visitor conditions based on the education category and other specifications

\begin{tabular}{|c|c|c|c|c|c|c|c|c|c|}
\hline \multirow{2}{*}{ Year } & \multicolumn{7}{|c|}{ Visitor Category } & \multirow{2}{*}{ Total } \\
\cline { 2 - 10 } & TK & SD & SMP & SMU & PT & Public & Tourist & Khusu & S \\
\hline 1 & 2 & 3 & 4 & 5 & 6 & 7 & 8 & 9 & 10 \\
\hline 2013 & 2699 & 4074 & 2233 & 2708 & 598 & 2046 & 128 & 505 & 14991 \\
\hline 2014 & 339 & 2731 & 2088 & 2176 & 371 & 1102 & 44 & 15 & 8866 \\
\hline 2016 & 4419 & 6091 & 2400 & 2102 & 804 & 4316 & 114 & 132 & 20378 \\
\hline 2017 & 1517 & 1419 & 1186 & 1393 & 1129 & 1557 & 30 & - & 8231 \\
\hline Total & 11595 & 19739 & 10127 & 10925 & 3340 & 11831 & 328 & 776 & $\mathbf{6 8 . 6 6}$ \\
\hline
\end{tabular}

Data source: Central Sulawesi Museum Visitor Data Document 2018

Based on the table above, it can be seen that foreign tourists are the smallest number of visitors, followed by special guests, following students, high school visitors, junior and kindergarten visitors and the highest visiting the museum is elementary school students, amounting to 19,739 people. There were no special visitors at all in 2017 but was quite high in 2013 at 505 visitors.

Based on the number of visitors that went to the museum, it was explained that during the last five years, as many as 68,661 visitors had visited with various interests or purposes. Most visitors come to see historical objects and look for 
materials for their schoolwork. Thus the recipients of da'wah through museums are quite diverse even though students dominate them.

To measure the level of visitors' interest in Islamic artifacts and the intention of visiting, a survey was conducted of 25 visitors (adults) as of July 2018. It may be necessary to explain that after the earthquake and tsunami in September 2018 to date, the conditions of Covid-19 were not optimal. So the material of this paper is the results of research conducted in June-August 2018.

Visitor Interests Against Islamic Artifacts

The people of Palu City have an interest in various Islamic messages in the museum. The level of visitors' interest in Islamic information can be seen in the following graph.

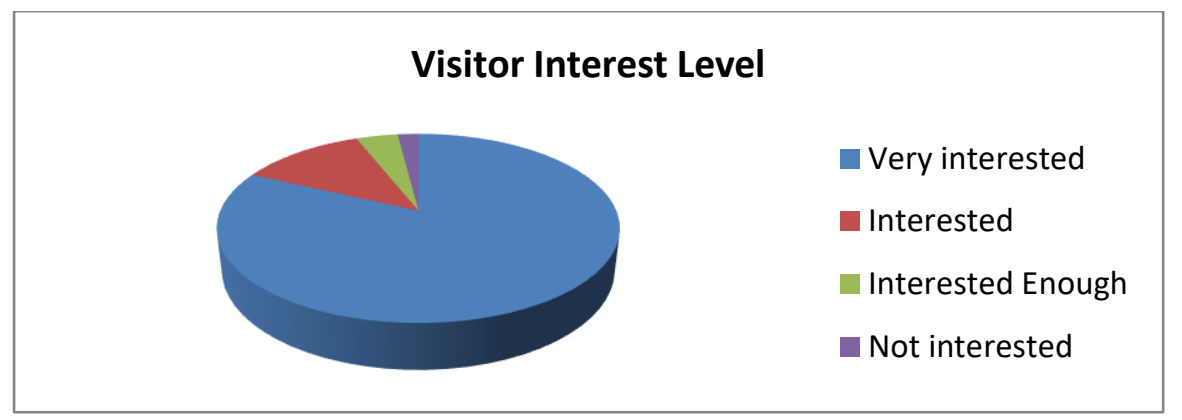

Based on the table above, it shows that the level of interest of visitors to Islamic artifacts in Central Sulawesi museums is very interested in having a value 8.2 (82\%), interested in having a value $1.2(12 \%)$, quite interested in having value 0.4 (4\%) and Uninterested only has a value of $0.2(2 \%)$. Thus, visitors interested in Islamic information in museums are bigger than those interested, quite interested, and not interested. 


\section{Visit Intention}

Visit intention with a sample of 25 people, which can be seen in the following graph;

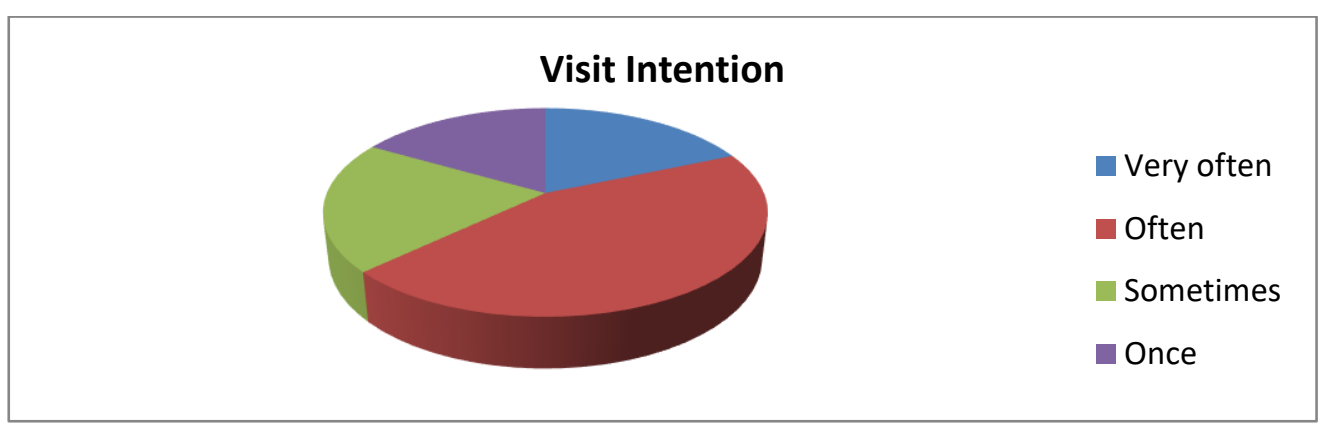

A survey of 25 visitors interested in visiting the museum was followed by the level of intention to visit the museum. Based on the survey results it was found that $19 \%$ was very frequent (value: 2 ), often $44 \%$ (value; 4,8 ), sometimes $20 \%$ (value; 2,2 ), and only once was $17 \%$ (value: 1,8 ). Thus, the level of interest is equivalent to the level of intention. Although "often" is greater than "very often". Why "often" can be considered the equivalent of "very interested" because the existing artifacts are unlikely to experience changes in content unless added if new artifacts are found related to existing artifacts. So frequent visits are enough to counterbalance being "very interested" at the level of interest.

The level of interest and intention of visiting the museum shows the interest and intention of cultural da'wah because of intense communication according to communication patterns or da'wah patterns that apply in museums where a person or group of people comes, observes, studies, and understands all things related to Islam and the culture that is influenced. Islam through repeated artifacts in the museums of Central Sulawesi. 


\section{Conclusion}

Museums, in general, are a means of learning as well as entertainment for the community. However, recently the museum has shifted its role in the dynamics of Muslim civilization in Indonesia, where the museum has become something that has the value of community pride for Muslims, making the museum a means of da'wah. Especially in museums that have Islamic historical and cultural values, which means that visitors will get Islamic messages (da'wah) in them.

Islamic messages can be obtained through Islamic artifacts, among others, Islamic books and texts, the Al-Qur'an, keris, traditional clothes, photos of the graves of Islamic figures (ulama/da'i), and various things related to these figures. as well as cultural artifacts that were influenced by Islam. Exploring Islamic messages by the museum system can be called a museum as a means of cultural da'wah. Through this cultural da'wah, visitors or the public can understand well about Islam and how Islam influences the cultural epicenter of the Palu people.

\section{References}

Aziz, Moh Ali, Ilmu Dakwah, Jakarta, Kencana, 2004.

Brown, K., \& Mairesse, F. (2018). The definition of the museum through its social role. Curator: The Museum Journal, 61(4), 525-539. https://doi.org/10.1111/cura.12276

ICOM ICOM Code of Ethics for Museums. Paris: International Council of Museums. 2013.

Helmi, Masdar, Dakwah dalam Alam Pembangunan, Semarang: CV Toha Putra.

Joseph-Mathews, S., Bonn, M.A., dan Snepenger, D. (2009), "Atmospherics and consumers' symbolic interpretations of hedonic services", International Journal of Culture, Tourism, and Hospitality Research, Vol. 3 No. 3, pp. 193-210.

Kementerian Agama RI, Al-qur'an dan Terjemahnya, Bandung, Fokus Media, 2010 
Komarac, T. (2014), "A New World for Museum Marketing? Facing the Old Dilemmas while Challenging New Market Opportunities", Trziste, Vol. 26 No. 2, pp. 199-214.

Mensch, Peter Van, The Musealisation of Knut. Dilemmas in the relationship between zoom and meseum, Comcol Newsletter N0.13 April 2011

Muhyiddin, https://republika.co.id/berita/q6ba9z320/ancol-resmi-jadi-lokasimuseum-rasulullah-saw-terbesar-dunia, diakses tanggal 16 Juli 2020.

Munawwir. A. W. Kamus al-Munawwir, Edisi ke-2, (Surabaya: Pustaka Progresif, 1997) h. 406-407

Muskat, M., Muskat, B., Zehrer, A., and Johns, R. (2013), "Generation Y: evaluating services experiences through mobile ethnography", Tourism Review, Vol. 68 No. 3, pp. 55-71.

Nielsen, J. K. (2015). The relevant museum: defining relevance in museological practices. Museum Management and Curatorship, 30(5), 364-378. https://doi.org/10.1080/09647775.2015.1043330

Nurdin, N. (2014). To Dakwah Online or not to Dakwah Online. Da'i Dilemma in Internet Age. Al-Mishbah :Jurnal Ilmu Komunikasi dan Dakwah, 10(1), 21-33.

Nurdin, N., \& Rusli. (2013). Spiritualising New Media: The Use of Social Media for Da'wah Purposes within Indonesian Muslim Scholars. Jurnal Komunikasi islam, 3(1), 1-21. http://jki.uinsby.ac.id/index.php/jki/article/view/55

Nurdin, N., \& Maddini, H. (2018). Sejarah Dakwah Dato Karama: Menelusuri Ulama Sumatera Barat Penyebar Islam Di Lembah Palu Al-Mishbah:Jurnal Ilmu Dakwah dan Komunikasi, 14(2), 205-239.

Radder, L. and Han, X. (2013), "Perceived Quality, Visitor Satisfaction and Conative Loyalty in South African Heritage Museums", International Business \& Economics Research Journal, Vol. 12 No. 10, pp. 1261-1272.

Roby Ardiwidjaja, Perspektif Masyarakat Terhadap Museum, https://www.academia.edu/4877338/Perspektif_Masyarakat_Terhadap_Muse um diakses tanggal 5 oktober 2018.

Ruben, Brend D, Komunikasi dan Perilaku Manusia. Jakarta, Rajawali Press, 2013.

Sukma, G. S. (2013, Pebruari 11). Museum Di Indonesia, Menyongsong Program Gerakan Nasional Cinta Museum. Retrieved April 2014, 18, from http://gilangswarasukma.blogspot.com: http://gilangswarasukma.blogspot.com/2013/02/museum-di-indonesiamenyongsong- program.html. 
Jurnal Hunafa: Studia Islamika, Volume 17, Number 2, p. 1-190

E-ISSN: 2355-7710

P-ISSN: 1411-125X

https://situsbudaya.id/museum-negeri-provinsi-sulawesi-tengah/diakses tanggal 30 Oktober 2018 